\title{
Articles
}

\section{The EU as a Role Model? - Innovative Maximum Standards for Suspects' and Defense Rights vs. International Minimum Standards}

\section{Sławomir Steinborn ${ }^{\star \star}$}

The article analyses the arguments which justify the harmonization of criminal procedures across the European Union, especially the adoption of the innovative maximum standards within the EU and the benefits which they can bring, as well as the potential drawbacks and threats tied to the introduction of these maximum standards. Inter alia, the judgment of the Court of Justice of the EU in the case Stefano Melloni vs. Ministerio Fiscal is seen as a one of the impulses, which could support the introduction of a common, EU-wide standard regarding the rights of the suspect. The article also indicates sample areas where it would be particularly desirable to develop the high, innovative standard for the protection of the rights of individuals. In conclusion, it is said that we need common, uniform standards that are as high as possible, because they would support the reasonable application of the principle of mutual recognition.

\section{Introduction}

The introduction through the Treaty of Lisbon of competence to the harmonization of procedural law (see Art. 82 II of the Treaty of Functioning of the EU ${ }^{1}$ ) has removed an obstacle, which was sometimes raised ${ }^{2}$, to adopt instruments aimed to approximate provisions of the law of criminal procedure in member states of the EU. It not only opens up a completely new perspective in taking harmonization actions, but also brings about the necessity to face new problems. One of the principal questions relates to what the relationship shall be between new standards introduced in the EU and the standards developed in a framework of the system of European Convention of Human Rights. The arguments in favor of the adoption of the innovative maximum standards within the European Union should be considered first, in addition to the benefits which they can bring. On the other

\footnotetext{
${ }^{\star}$ Revised version of presentation held on a seminar organised by European Criminal Policy Initiative, Ludwig Maximilian University, Munich, 5th and 6th July 2013.

*^ Professor Sławomir Steinborn, University Gdansk

${ }^{1}$ See e.g. H. Satzger, Internationales und Europäisches Strafrecht, Baden-Baden 2009, p. 174-175; B. Noltenius, Strafverfahrensrecht als Seismograph der Europäischen Integration - Verfassung, Strafverfahrensrecht und der Vertrag von Lissabon, ZStW 2010, vol. 3, pp. 608 et seqq.

${ }^{2}$ It has been sometimes raised doubts during the works on proposal of framework decision on certain procedural rights in criminal proceedings, if Art. $31 \mathrm{I}$ of the Treaty of European Union provides for a competence for the EU to harmonize procedural law - see J. Polakiewicz, Durchsetzung von EMRK-Standards mit Hilfe des EU-Rechts? Chancen und Risiken Europäischer Rechtsetzung erläutert am Beispiel der Verfahrengarantien in Strafverfahren, Europäische Grundrechte Zeitschrift 2010, vol. 1-5, p. 15; R. Esser in: U. Sieber, F. H. Brüner, H. Satzger, B. von Heintschel-Heinegg (ed.), Europäisches Strafrecht, Baden-Baden 2011, p. 834.
} 
hand, one could ask whether it would not be better to stick to the "good old" minimum standards, which are contained, for instance, in the case law of the European Court of Human Rights (ECHR). We also need to be aware of the drawbacks and threats tied to the introduction of maximum standards, which may be a premise for abandoning this idea.

\section{Arguments for the maximum standards}

Undoubtedly, the principal factor which justifies the need to harmonize criminal procedures across the European Union is the cross-border nature of criminal proceedings in the Member States. The increased mobility of citizens who work or study in countries other than their country of birth or own places of residence or assets in various Member States, the development of the common market and tourism - all these phenomena mean that nowadays we deal with foreign elements in the criminal process much more frequently than some 20-30 years ago. This difference is particularly noticeable in Poland. It is estimated that around two million Polish citizens reside temporarily in other countries of the EU, which poses a challenge for the judicial systems, both in Poland and in other Member States. The disappearing state borders mean that the European Union appears as a single state in many areas of life - especially from the perspective of an individual. It would not be just or fair if individuals who find themselves in the same situation - as the suspect or as the victim - were to be treated differently in the course of criminal proceedings simply because they are staying in the territory of another Member State.

If we discuss the need for harmonization due to the cross-border nature of criminal proceedings, the question arises immediately on the areas to be covered by the new, common standard for the rights of the suspect and of the defense. Should they be limited only to those which are closely linked to the cross-border nature of the criminal case, such as the right to an interpreter, the foreigner's right to contact the defense counsel and the consul of his/her state, cooperation on the basis of the European arrest warrant, mutual recognition of judgements, or international legal assistance? I believe this should not be so. In real life, it is very difficult to divide the rights of the parties into ones that would only have either a national or cross-border nature. Each procedural safeguard or a measure that interferes with the individual's rights can be applied both in cross-border and domestic criminal proceedings. This depends solely on purely factual circumstances. Even if we attempted such a differentiation, this move would be completely pointless. How could one rationally justify the fact that Member States ensure a high standard for the rights of parties under cross-border criminal proceedings, and do not provide the same standard with respect to national rights? It also appears that it would be unjustified to limit the harmonization of procedural criminal law and to build a common, high standard of rights only with respect to cross-border proceedings, while omitting the nationalonly proceedings. For a suspect who wishes to exercise his/her rights, the fact whether the given proceedings is of domestic or cross-border nature is completely immaterial. Otherwise, in order to apply a specific coercion measure, such as phone 
tapping, in the cross-border proceedings it would be necessary to obtain a prior court decision, while the same measure under national proceedings could be applied on the basis of a decision issued either by the prosecutor or by the court. Different standards of rights would breach the rule of equality of the law, provided in the constitutions of most European countries. Moreover, this could lead to a further lowering of standard in domestic proceedings.

There are further arguments in favor of the development of a common standard for the rights of the parties in all criminal proceedings within the EU. The importance of harmonization of the procedural criminal law and of building a common standard of procedural rights for the better functioning of mutual recognition and for the strengthening of mutual trust between the judicial systems of Member States has been discussed many times. Common, possibly high standards would certainly contribute to the development of common, European legal awareness regarding the protection of individual's rights in criminal proceedings. A person involved in criminal proceedings - either as the suspect or as the victim - would be aware of what to expect, regardless of the location of said proceedings.

The situation would become additionally complicated with the establishment of the office of the European Public Prosecutor ${ }^{3}$. Aside from procedural regulations of the individual Member States, this would mean the appearance of additional procedural regulations, common across all Member States - which would only apply however to a specific category of cases, namely offences against financial interests of the EU. Thus, the differences between the standards of rights could become even more pronounced. This is a strong argument in favor of the development of the highest possible common European standard, not limited to a specific category of cases.

\section{Potential threats}

There are also certain threats tied to the adoption of maximum common standards across the EU. First of all, the adoption of common high standards would, on one hand, lead to more frequent need for exceptions (for instance, due to the need to effectively combat terrorism or organized crime), and on the other hand, it would be more difficult to grant such exceptions only to certain Member States, which need it (e.g. those having problems combating serious organised criminality).

Another difficulty is tied to the risk of conflicting interpretations between the European Court of Human Rights (ECHR) and the Court of Justice of the European Union, which would be inevitable if the scope of standards regarding the rights of the suspect and of the defense were to correspond to the standards provided for under the European Convention on Human Rights. This argument has been raised, in particular, during the discussion, held a few years ago, on the proposal for

\footnotetext{
${ }^{3}$ See Proposal for a Council regulation on the establishment of the European Public Prosecutor's Office (COM $2013 / 534$ final).
} 
a framework decision on certain procedural rights in criminal proceedings ${ }^{4}$. It leads to a certain conclusion, important for our musings: it is completely pointless to harmonize procedural rights on the level of the minimum standard, guaranteed by the European Convention on Human Rights. If we want the cooperation between EU Member States to generate some value added for the existing system of protection of individuals' rights during the criminal proceedings, we should strive to adopt a high standard for their protection, one that would correspond to the constitutional standard of rule of law (Rechtstaatsprinzip). Only in such a case would the European Union stand a chance of becoming a role model, determinant of the standards for the rights of the parties in criminal proceedings. In such situation, the higher the standards of procedural rights in the European Union, the lower the risk of conflict between the ECHR and the Court of Justice of the European Union, even though it cannot be fully avoided. According to those remarks, it could be doubtful if it is necessary to adopt a directive on the strengthening of certain aspects of the presumption of innocence and of the right to be present at trial in criminal proceedings ${ }^{5}$, at least in a form adopted in the proposal from 27 November 2013, when its provisions in principle duplicate a standard developed in the case-law of ECHR. Such a directive has no real value added.

An opposite evaluation shall be expressed about the proposal of the directive on provisional legal aid for suspects or accused persons deprived of liberty and legal aid in European arrest warrant proceedings ${ }^{6}$. It appears that the proposed standard of the access to the provisional legal aid is higher than that which stems from the caselaw of the ECHR within the framework of so called "Salduz doctrine", It follows that every person suspected to have committed a crime and arrested shall have right to access to defence counsel, but only vulnerable suspects, whom are not capable of understanding information about their right to remain silent, e.g. children, alcoholics, should in every case be provided with legal assistance before their first interrogation. The proposal of the directive justly tends to grant suspected and accused persons the possibility of having access to provisional legal assistance ex officio immediately after the deprivation of liberty and before any interrogation.

Neither can one pass over the current legal framework for harmonization, which is set by the treaties. Article 82 section 2 of the Treaty on the Functioning of the European Union defines the foundations for the establishment by the EU of standards regarding the rights of individuals in criminal proceedings. First of all, this provision refers exclusively to the scope necessary to facilitate mutual recognition of judgments and judicial decisions, as well as improving cooperation between the police and the judicial authorities in cross-border criminal cases. Secondly, these standards are supposed to be minimum ones. Of course, this does not preclude these

\footnotetext{
${ }^{4}$ See B. M. Zupančič, J. Callewaert, Relationship of the EU Framework Decision to the ECHR: Towards the fundamental principles of criminal procedure, ERA Forum 2007, vol. 8, pp. 268-269.

${ }^{5}$ COM 2013/821 final.

${ }^{6}$ COM 2013/824 final.

${ }^{7}$ Salduz v. Turkey, no. 36391/02, judgment of 27 November 2008; Panovits v. Cyprus, no 4268/04, judgement of 11 December 2008; Płonka v. Poland, no. 20310/02, judgment of 31 March 2010.
} 
minimum standards from ensuring an appropriately high level of protection. However, one needs to be aware that this regulation expresses the attitude of Member States towards the harmonization of procedural criminal law, including the development of a common standard for the protection of individual in the course of criminal proceedings. This attitude appears to be rather restrained.

If we decide that the European legislator should guarantee an appropriate level of effective protection for an individual's rights during criminal proceedings, we have to be aware that it is not realistic to expect that it would be done rapidly, over a short period of time. A pointed example is the fiasco of the proposed framework decision on certain procedural rights in criminal proceedings 8 . The small steps approach, which involves the adoption of the right solutions for fragmentary issues, certainly stands a better chance for success. It is also worth stressing that it is necessary to adopt solutions that determine specific standard of protection. The clauses, used sometimes by the European legislator in the motives or provisions of framework decisions and directives that refer to instruments based on the principle of mutual recognition for rules and fundamental rights set forth in the treaties and the Charter of Fundamental Rights of the European Union, do not have a strong practical significance. Their usefulness for the development of appropriate protection standards turns out to be low.

\section{Some implications of the Melloni case}

An additional impulse to support the introduction of a common, EU-wide standard regarding the rights of the suspect - one that would significantly exceed the minimum standard guaranteed by the European Convention on Human Rights - stems from the judgment of the Court of Justice of the European Union in the case Stefano Melloni vs. Ministerio Fiscal'. In paragraph 63, the Court said: "allowing a Member State to avail itself of Article 53 of the Charter to make the surrender of a person convicted in absentia conditional upon the conviction being open to review in the issuing Member State, a possibility not provided for under Framework Decision 2009/299, in order to avoid an adverse effect on the right to a fair trial and the rights of the defence guaranteed by the constitution of the executing Member State, by casting doubt on the uniformity of the standard of protection of fundamental rights as defined in that framework decision, would undermine the principles of mutual trust and recognition which that decision purports to uphold and would, therefore, compromise the efficacy of that framework decision". In its essence, the stance taken by the Court of Justice means that the Member States should sacrifice their high constitutional standards for the protection of individuals during criminal proceedings on the altar of the mutual recognition principle. Such measure could be understandable if its purpose was to extend the freedom of an

\footnotetext{
${ }^{8}$ COM 2004/328 final.

${ }^{9}$ Judgment from 26 February 2013, C-399/11.
} 
individual or to strengthen the common market. In this case however, the use of the argument of primacy of EU laws in order to justify the rejection of a national constitutional standard that grants higher protection of an individual is nothing short from astounding. The argument used by the Court that granting primacy to the higher national constitutional standard would compromise the principle of mutual trust, seems to be an error; and the interpretation of Article 53 of the Charter by the Court basically means that it becomes completely redundant. It seems, therefore, that the Court judgment in the Mellloni case would open the path and grant permission to lower the standards for the protection of rights of an individual in criminal proceedings. Those Member States where the standard of protection is higher than the minimal one shall be in fact forced to waive it, at least in crossborder cases. Where the recognized rights of the suspect and of the defense hinder the effective application of the mutual trust principle, those Member States will have to yield, because the minimum standard is sufficient, according to the Court. Such line of reasoning turns the whole issue upside down! The conclusions stemming from this particular Court judgment are clear. In order to prevent the degradation of national standards, it is necessary to strive for the development of an EU-wide, appropriately high standard for the protection of rights of the suspect and the defense.

\section{Potential areas for setting innovative standards}

Let's attempt to indicate sample areas where it would be particularly desirable to develop the high, innovative standard for the protection of the rights of individuals.

The functioning of the European rule ne bis in idem, laid down in Article 54 of the Convention implementing the Schengen Agreement, is a powerful example of the serious defect - the lack of an effective mechanism that would eliminate parallel proceedings conducted in different Member States with respect to the same act. The breach of the fundamental rights of an individual involves not only a repeated trial and punishment for the same act, but also the double, or multiple prosecutions. Each criminal proceeding is tied to serious hardships for the defendant, such as the risk of pre-trial (temporary) detention or restriction of liberty during the course of the proceedings, the need to participate in court trials, to seek the assistance of defense counsel and to cover its costs. In the case of criminal proceedings conducted in a Member State other than the defendant's country of residence, these hardships are compounded. Such a situation is certainly an infringement of the defendant's rights, as the hardships tied to criminal proceedings conducted against an individual should not be multiplied. However, the provisions of the framework decision 2009/ 948/JHA of 30 November 2009 on prevention and settlement of conflicts of exercise of jurisdiction in criminal proceedings ${ }^{10}$ do not foresee at all a mechanism that would force the termination of one of the parallel proceedings. This mechanism is completely ineffective and requires a fundamental, rapid change.

\footnotetext{
${ }^{10}$ Official Journal L 328 of 15 December 2009, p. 42-47.
} 
The standard regarding the right to use the assistance of a defense counsel also merits special attention. Under the predominant approach, the standard stemming from Article 6 of the European Convention on Human Rights does not apply to proceedings which involve granting assistance to another state which conducts the proceedings - such as extradition proceedings, enforcement of the European arrest warrant or the transfer of prisoners ${ }^{11}$. The states where such proceedings are carried out would be free not to grant the person involved even the minimum standard of protection of his/her rights in the course of criminal proceedings, as stemming from Article 6 of the European Convention on Human Rights. It is very difficult to accept this, as the fact of procedural acts being carried out in two different states additionally complicates, instead of facilitating, the defense. The person against whom the criminal proceedings take place in the requesting state should be treated in the requested state as if proceedings were taking place in that country. In other words, these proceedings should be treated as one, with each of the states responsible for its particular section. It is therefore necessary to develop a common standard, with respect to, among other issues, the rules for obtaining free legal assistance. The defense counsel from the requesting state knows the case best, but he/she may not always have the time and funds to participate in foreign procedural acts. On the other hand, the nomination of a second defense counsel in the requested country may simply exceed the defendant's financial capability. Meanwhile, an effective control of proceedings carried out in the requested country may be, in fact, performed only by a defense lawyer from that country - one who knows the system, local procedures and the language, and is able to meet the deadlines simply by virtue of being where he is needed. A defense counsel in cross-border proceedings must be guaranteed appropriate conditions for the effective performance of his/her duties. This involves such issues as possibility to contact the defendant, to obtain information on the proceedings and to access the case files. Therein lies another problem, tied to the fact that the case files are usually kept in the requesting state. It would therefore be useful to create an opportunity for remote access to them - e. g. if case files are kept in electronic form, access could be possible via the Internet.

In this context provisions set in directive 2013/48/EU of 22 October 2013 on the right of access to a lawyer in criminal proceedings and in European arrest warrant proceedings, and on the right to have a third party informed upon deprivation of liberty and to communicate with third persons and with consular authorities while deprived of liberty ${ }^{12}$ should be positively reviewed, because it sets a common standard of access to a defence lawyer in proceedings concerning a European arrest warrant.

\footnotetext{
${ }^{11}$ See K. and F. v. the Netherlands, no. 12543/86, Commission decision of 2 December 1986; Maaouia v. France, no. 39652/98, judgment of 5 October 2000, § 40; Peñafiel Salgado v. Spain, no. 65964/01, ECHR decision of 16 April 2002; Sardinas Albo v. Italy, no. 56271/00, ECHR decision of 8 January 2004; Mamatkulov and Askarov v. Turkey, no. 46827/99 and 46951/99, judgment of 4 February 2005, § 82; Monedero Angora v. Spain, no. 41138/ 05, ECHR decision of 7 October 2008.

${ }^{12}$ Official Journal L 294 of 6 October 2013, p. 1.
} 
There is an analogous situation on the basis of Art. 5 ECHR. When during the proceedings of execution of an EAW requested person is arrested and detained, what falls within the scope of Art. $5 \S 3$ (f) ECHR, the guarantees provided for in Art. $5 \S 3$ ECHR do not apply to this person, first of all right to be brought promptly before a judge. This guarantee is applied to this person first after his/her surrender to the state, where the EAW was issued in relation with criminal proceedings pending in this state. Whereas in the EU it is endeavoured to possibly full implementing of the principle of mutual recognition, it shall be not done selectively. When the judicial decision issued in one member state shall be recognized in another one, as it would have been a domestic judicial decision, the person that this decision refers to, shall also dispose of analogous legal means against this decision and shall come within analogous guarantees, as these proceedings would have taken place in just one member state. The requested person shall be brought before a judge already in a moment of his/her arrest with a view to execute an EAW, because already in this moment it is necessary to review lawfulness and factual grounds of his/her detention. It refers especially to a situation when the EAW was issued for the purposes of conducting a criminal prosecution against this person.

Further important issues tied to the suspect's rights include the definition of moment from which the suspect has the right to legal assistance, the right to receive understandable information on the charges against him and on his rights and obligations, or the right to be present during the procedural acts, especially in the court trial. Under the cross-border proceedings, the defendant often faces a dilemma: to participate in the trial and in the defense, which can be costly in the case of a significant distance to the court where the trial is held; or to waive one's own participation in the trial, surrendering oneself to fate. Sometimes there is another alternative, between voluntary appearance in court and the threat of a European arrest warrant being issued. The European solutions should facilitate the defendant, to the maximum extent possible, the opportunity to exercise the right to participate in the trial and other procedural acts, using various techniques available, such as videoconference.

One cannot forget those areas whose nature is perhaps not directly cross-border, but which certainly are important for the protection for the defendant's rights. I have in mind the whole area of measures which intervene with the rights and freedoms of an individual. They can be used both in domestic and cross-border proceedings. The postulate, contained in the Manifesto, stating that such measures should be applied in a uniform manner, on the basis of decisions issued by a judge and not by other authorities, such as the prosecutor, is therefore pertinent.

\section{Conclusion}

The answer to the question placed in the title of this paper is not simple - and it cannot be explicit. One of the frequently used words was "common". This was intended. Perhaps the achievement of maximum standards for the rights of the 
suspect and the defense is a process that shall require more time. However, I have no doubt that we need standards that would be common, uniform and as high as possible - because they would support the reasonable application of the principle of mutual recognition. These standards should not, however, lose their "minimum" nature - in the sense that they should not preclude Member States from adopting a higher level of protection of individual's rights during criminal proceedings, and such a higher level should be respected by the other Member States. 